\title{
Research on Teaching Reform and Innovation of International Trade Practice
}

\author{
Chunxia Huang ${ }^{1}$, Dashan Niu ${ }^{2}$, Lei Yao ${ }^{3}$ \\ ${ }^{1}$ Cangzhou Technical College, Cangzhou, Hebei, China, 061001 \\ hunter2011@foxmail.com
}

Keywords: Reform and Innovation; International Trade Practice; Curriculum System

\begin{abstract}
According to the requirements of vocational training objectives, international trade major should adapt to economic and social needs of local industrial structure. This paper conducts research on international trade reform, focuses on the diversification of the revised plan from teaching, curriculum design, main courses, teaching content and methods, vocational skills training and other aspects of strengthening research and practice. This paper tries to explore a new way to adapt to the needs of international trade practice expertise personnel training for enterprises.
\end{abstract}

\section{Introduction}

Professional training of students of international trade should master the international economy and international trade of basic knowledge and basic skills, to engage in international trade practice; understand the development of contemporary international trade; familiar with the practice prevailing international trade rules; proficient WTO rules and Chinese foreign trade policies and laws; must have strong diplomatic skills, which can be engaged in the coordination of practical business, management, research and advocacy planning in foreign sector enterprises; Also has practical skills and creative abilities. The culture must focus on the practical operation and process control trade, foreign trade and domestic trade appropriately dilute the boundaries of the principle of actual, practical, effective, quality training will combine the knowledge and ability to meet the needs of business and society.

Talents curriculum system is the core element to achieve goals, to develop strong employability highly skilled person, we need to have a scientific and rational curriculum. In the curriculum system design, adhere to the principle of employment-oriented, personnel training to comply with the law applied technology, capacity building constructed around vocational curriculum, the rational design of curriculum architecture. Curriculum system is divided into theoretical teaching and practical teaching module. Curriculum Design, the first is the practice of teaching content design, practical teaching curriculum design should become the main line and the body, around the teaching objectives require a variety of professional development and training of special ability to design practical teaching links and content, on the basis of search and find on students' knowledge blind spot, accordingly design the appropriate necessary, enough theoretical teaching system. Theory for the practice of teaching content and services, the proportion of theory and practice of teaching is reflected in higher vocational education 1:1 basic features. In the design of curriculum system on the set of the four teaching modules. That is the basic quality capability module, professional knowledge capacity module and skills capacity modules, application capability module (practice teaching).

The basic quality and ability of teaching modules. The modules include: (1) Compulsory courses: political theory, economic mathematics, English, sports and other total hours of 26\%; (2) Elective courses: language, social sciences, humanities and the total hours of $4 \%$; this module is based on culture and improve the quality of students, so that students physical and mental qualities and ability to meet the future requirements of cognitive learning and working established.

Professional knowledge of capacity modules. The modules include: (1) Compulsory courses: International Economic Law, International Commercial Law, international trade theory and practice, basic accounting, statistics based on the international financial, Introduction to the socialist market 
economy, law, economics, management science, web design, $15 \%$ of the total hours; (2) Elective courses: Introduction to electronic commerce, international investment, consumer psychology, market research and market forecast of $5 \%$ of the total hours; the purpose of this module is to train students specialized basic knowledge and ability, and lay a good foundation for subsequent learning modules.

Professional knowledge and skills for capacity modules. The modules include: international marketing, international business practices documents, with a single trade practices, trade correspondence, customs practices, Business English, Business English, international business negotiations, international settlement and other courses, $23 \%$ of the total hours. This module focuses on students of professional knowledge and skills ability to improve students' ability to analyze and solve problems, and to lay the foundation for the practical aspects.

\section{Reform of Teaching Methods, Teaching Content and Teaching Methods}

Teaching methods, teaching content is the core of the reform of teaching reform, to reflect the students' practical ability and practical innovation skills, professional work after graduation in International Trade ability. Ability to target, in addition to more reasonable to develop appropriate teaching system and syllabus, while focusing on reform requirements and research methods, means in the teaching process. International trade practice is highly professional practical operation, and therefore do not emphasize too much theoretical teaching in the teaching process, and focus more repeated practice, which enhance students' practical skills.

Reform of The Teaching Content and Ideas. The research content into the teaching content. To Course content and professional skills required combination, we will research the content into professional courses within that curriculum more relevant, practical, and improve student skills and ability to solve practical problems. Such as International Business Dan Zhengyuan, Merchandiser, customs, and other e-commerce division assistant gradually formed research library and recommended that students have a variety of job priority qualifications to work, reflecting employment-oriented teaching.

The part of the course bilingual teaching. International trade occupation requires employees must have a high level of English, in order to make teaching contents more practical work we put Business Correspondence, international business practices documents, with a single trade practice bilingual teaching curriculum, so that students can make better use of English business exchanges.

Streamline curriculum cross duplicate content, highlight curriculum teaching focus and character.

To strengthen the construction of teaching materials, teaching content According to the professional development needs, adjust to enrich teaching materials, research materials research class selection.

The creation of cross composite courses. The full development of information technology in the network today, ITC business has implemented paperless office, so students must master some basic skills related to networking. To this end we opened a network marketing, e-commerce Introduction to simulate practical operation of e-commerce courses, reflecting the trends and needs of the professional development, highlighting the professional features.

Explore of Teaching Methods. In the reform, we mainly on international trade practice (law) part of the main courses of professional conduct exploration, flexible teaching methods and means, constitute a distinctive teaching model.

Statistics course. In the process of teaching basic courses in statistics, first introduced to the students the basic theory, then lists the topics of coursework guidelines and specific requirements, in order to investigate the form of packets. Draw conclusions and complete statistical report. Through this practical training, improve the students deal with the use of statistical knowledge to analyze practical problems.

Business English teaching scenarios. Practice teaching of the course includes teaching and case teaching listening in mind. Case teaching is mainly through various modules (such as hearing, original foreign film appreciation, role-playing, etc.) training to improve students' business English 
listening, speaking, reading and writing abilities. Upon hearing the teaching is used in business activities common situational approach. The main scenario training activities organized students, such as: employment interview, company business negotiations, marketing, general commercial work, commercial translation by situational teaching, enhance students 'teamwork and innovation, to improve students' ability to use English for business operations.

International marketing case teaching. Case teaching major has success cases in international marketing by introducing a number of well-known multinational companies, in the form of guidance to inspire students to learn, and organize students in small groups to carry out academic activities. Let students perceptively recognize the importance of international marketing, as well as its features and tasks. The course content is practical teaching students business marketing design, planning and countermeasures for students to try to corporate marketing. After such training, so vivid theoretical course into practice lessons to improve students' ability to analyze and solve practical problems.

International business Documents program operation pedagogy. An important aspect of curriculum reform is to combine the local economy courses practical, so that students can go to work after graduation to work directly posts. In teaching the lesson, teachers collect local foreign trade enterprises commonly used document types available to students, according to the international business process documentation procedures require students to simulate the operation of the program, so that students get a realistic teaching. In merchandise trade documents for the training of local program operation pedagogy, both students of vocational skills training, and pay attention to the teaching content, the students' professional quality, to make our culture more practical significance.

\section{Problems in Teaching Reform}

Teachers in the theory and practice with light weight concept still exists. Although we reform the education system, increasing the proportion of class practice, but in the actual teaching, many teachers still more to follow the traditional way of teaching the theory and practice of light weight, in the inertia of thinking, teachers involuntarily biased teaching theoretical, to speak less practical teaching content, thus making the implementation of reform programs affected.

Due to the multi-reason construction progress is slow practice bases. Currently student internships are in more decentralized method of placement, job training that cannot be arranged, the lack of stable off-campus practice base, thus making the implementation of reform programs have greater difficulties.

Comprehensive quality faculty, education level and title structure needs to be improved and optimized. Quality of teachers constitute determine the quality of personnel training and college teaching. Currently in part-time teachers in colleges, both have a profound theoretical teaching skills but also has a wealth of practical work experience teachers less, thus building a stable part-time dual-qualified teachers imminent.

\section{Consideration on Design of Teaching Reform}

Through the practice of the previous stage of reform, we find in school to improve student learning, promote student vocational skills, ability and practical ability, to improve the teaching reform of graduate employment rate the main purpose, whether it is from the perspective of research and practice both in terms of a long-term and arduous task, the future direction of reform should always meet the needs of the Guangdong Foreign Trade and foreign trade structure of personnel quality requirements.

Combination internship bases, double-qualified teachers to promote the construction. Combination is the only way for the development of vocational education. Higher education business is an important part of the process, it is an important platform for students to practice and employment. In practice base, we can fully rely on the business and technical personnel to guide students internships and professional skills training, as well as school teachers led professional 
practice in enterprises together with the students to participate in practical training, practical ability to obtain the appropriate exercise and improve. Thus, Combination promote the theory and practice of combining improving the quality of teachers, build a reasonable structure for the college part-time dual-qualified teachers to provide a strong guarantee.

In the teaching reform, reflecting the culture of the principle of employment-oriented. According to economic and trade development needs of the region, further adjustment and reform teaching system, teaching content as close to the actual first line of foreign trade enterprises, in order to truly improve students' professional practical skills, creativity, and student occupational capacity for sustainable development in the future, the real Training Principles embody employment-oriented.

Curriculum system reform needs outstanding professional characteristics. Curriculum system reform is to train students in the basic work of professional competence. Through curriculum system reform, we should make efforts to build professional characteristics. Set subjects in improving curriculum, teaching methods, combining teaching and research to improve the management of the breakthroughs and innovation. Learn from the successful experience of domestic, international vocational education reform, local economic and social needs, we should make comprehensive education reform, highlight the school characteristics.

\section{References}

[1] Y.B. Cai, T.S. Liu, W.H. Song. International Trade Application Personnel Training Goal and Pattern Research. Shaoguan University: Social Science, 25 (1): 16-19.

[2] L. Yang. Super Reform Practice Teaching Strengthen the Employability of Students. Higher Education Forum, 25 (2): 18-113.

[3] G. Qiu. Teaching and Curriculum Reform Practice. China Science And Technology Information, 26 (22): 28-281.

[4] L.Y. Liu. International Trade and Economic Restructuring of Curriculum Structure. Modern Education Science: Higher Education Research, 26 (6): 128-129. 